методичний комплекс як засіб розвитку творчого мислення / I. I. Власенко // Історія та правознавство. - 2012. - № 19-21. - С. 11-14. 3. Десятов Д. Л. Деякі аспекти використання історичного документа/ Дмитро Леонідович Десятов// Історія та правознавство. - 2006. - № 26. - С. 3-7. 4. Задорожна Л. Навчити працювати самостійно (Інтеграційний метод роботи 3 історичними документами)/ Лілія Задорожна // Історія в школах України. - 2004. - № 5. - С. 7-10. 5. Киселева Ю. В. К проблеме формирования критического мышления студента вуза [Електронный ресурс]/ Ю. В. Киселева // Credo New. - 2012. -№1. - Режим доступу: http://www.intelros.ru/readroom/credo_new/credo-new-2012-1/13145-.html б. Ковбасюк Т. Традиції та новації у використанні писемних джерел на уроках історії України / Тетяна Ковбасюк // Історія в школах України. - 2008. - № 11-12. - С. 46-48. 7. Ліпмен М. Значення філософії для демократії обговорення / Мет’ю Ліпмен // Рідна школа. - 2001. № 4. - С. 61-64. 8. Михайлов Ф. Т. Культурология как основание общего человековедения / Феликс Трофимович Михайлов //. Михайлов Ф. Т Избранное. - М. : Индрик, 2001. - С. 257-400. 9. Саюк В. Ігрові методи та їх дидактичне значення/ Валентина Саюк// Рідна школа. - 2001. - № 4. - С. 18-20. 10. Святокум О. Застосування колективних форм у роботі з текстовими джерелами в основній школі / Оксана Святокум // Історія в сучасній школі. - 2013. - № 1. - С. 27-33. 11. Страдлинг Р. Преподавание истории Европы XX века: [монографія] / Роберт Страдлинг.- Страсбург : Совет Европы, - 2002. - 289 с. 12. Терно С. Світ критичного мислення: образ та мімікрія / Сергій Терно// Історія в сучасній школі. - 2012. - № 7-8. - С. 27-39. 13. Турянська О. Методи особистісно-орієнтованого навчання в школі/ Ольга Турянська // Історія в шк. України. - 2002. - № 1. - С. 27-32.

\title{
СУТНІСТЬ І СТРУКТУРА ГОТОВНОСТІ МАЙБУТНЬОГО ВЧИТЕЛЯ ПРИРОДНИЧО-МАТЕМАТИЧНИХ ДИСЦИПЛІН ДО ПЕДАГОГІЧНОГО ПРОЕКТУВАННЯ ЗАСОБАМИ ІНФОРМАЦІЙНИХ ТЕХНОЛОГІЙ
}

Перець О. Б. Сутність і структура готовності майбутнього вчителя природничоматематичних дисциплін до педагогічного проектування засобами інформаційних технологій.

У статті проаналізовано проблему готовності майбутнього вчителя природничоматематичних дисциплін до педагогічного проектування засобами інформаційних технологій. Визначено й обгрунтовано поняття означеної готовності та схарактеризовано іiї компоненти з відповідними елементами.

Ключові слова: підготовка, готовність, готовність майбутнього вчителя природничо-математичних дисциплін до педагогічного проектування, педагогічне проектування, засоби інформаційних технологій.

Перец О. Б. Сущность и структура готовности будущего учителя естественноматематических дисциплин к педагогическому проектированию средствами информационных технологий.

В статье проанализирована проблема готовности будущего учителя естественноматематических дисциплин к педагогическому проектированию средствами информационных технологий. Определено и обосновано понятие заявленной готовности, охарактеризованы ее компоненты с соответствующими элементами. 
Ключевые слова: подготовка, готовность, готовность будущего учителя естественно-математических дисциплин к педагогическому проектированию, педагогическое проектирование, средства информационных технологий.

Perets O. B. The content and structure of readiness of the future teacher of natural and mathematics disciplines to the pedagogical planning by means of information technologies.

In the article the problem of readiness of the future teacher of natural and mathematical disciplines to the pedagogical planning by means of information technologies has been analyzed. The content of the above mentioned readiness of the future teacher of natural and mathematical disciplines has been defined and scientifically grounded.

Key words: training, readiness, readiness of the future teacher of natural and mathematical disciplines to the pedagogical planning, pedagogical planning, tools of information technologies.

Актуальність дослідження зумовлена потребою в підготовці нової генерації педагогів-професіоналів, які, володіючи фундаментальними теоретичними знаннями, вміють творчо використовувати їх у проектуванні педагогічних процесів і систем, зорієнтованих на формування всебічно розвиненої особистості випускника загальноосвітньої школи, адаптованого до творчої життєдіяльності в умовах інформатизованого суспільства.

Стан розробленості проблеми в науково-педагогічній літературі свідчить, що окремі аспекти підготовки майбутніх учителів до педагогічного проектування розроблені як у вітчизняній, так і в зарубіжній педагогічній науці. Досліджено питання зародження i становлення ідей проектної педагогіки (В. Безрукова, Дж. Дьюї, А. Кузнецов, А. Макаренко, С. Русова, К. Ушинський, Н. Яковлева та ін.), дидактичні засади проектної технології та методу проектів (Г. Ізотова, О. Коберник, О. Крутський, В. Мельник, Н. Орлова, С. Полат, О. Тулупова та ін.), їх використання у процесі викладання природничо-математичних дисциплін (О. Гудирева, Т.Жиденко, Г. Поволяко, В. Романенко, О. Ткаченко, В. Шарко та ін.). Різнобічним дослідженням у галузі формування готовності студентів вищих педагогічних навчальних закладів до педагогічного проектування в руслі підготовки до професійно-педагогічної діяльності присвячені роботи І. Богданової, А. Богуш, Е. Карпової, З. Курлянд, А. Линенко, I. Підласого, В. Сластьоніна та ін.

Мета статті полягає у визначенні й теоретичному обгрунтуванні сутності і структури готовності майбутнього вчителя природничо-математичних дисциплін до педагогічного проектування засобами інформаційних технологій.

Науково-педагогічні пошуки останніх років, актуалізовані швидкою комп'ютеризацією всіх галузей суспільного буття, глобалізацією інформаційно-освітніх процесів, потребою входження України в трансконтинентальну систему комп'ютерної інформації, що окреслено Державною програмою «ннформаційні та комунікаційні технології в освіті і науці», вимагають зосередження уваги на використанні сучасних інформаційних технологій у професійній підготовці майбутніх учителів і формуванні готовності до їх використання у професійній діяльності (І. Богданова, Р. Гуревич, Р. Гурін, М. Жалдак, Т. Койчева, Н. Морзе, І. Підласий, О. Співаковський та ін.). Наголошуючи на важливості проведених досліджень, водночас зазначимо, що проблема підготовки студентів природничо-математичних спеціальностей до проектнопедагогічної діяльності засобами інформаційних технологій у зв'язку 3 іï багатогранністю не знайшла остаточного розв'язання. 
Наразі педагогічною спільнотою термін «готовність» використовується досить широко, хоч і з різними тлумаченнями. У зв'язку з цим ми звернулися до аналізу психолого-педагогічних джерел, у яких досліджуються проблеми підготовки та готовності особистості до різних видів діяльності.

Так, на думку М. Клімової, наявні три підходи до визначення сутності поняття «готовність людини до різних видів діяльності»: 1) готовність як особливий психологічний стан особистості (функціональний підхід); 2) готовність як психологічна настанова; 3) готовність як система якостей (властивостей) і стану особистості (особистісний підхід) [3]. Прихильники першого підходу (М. Виноградов, Н. Левітов, О. Ухтомський та ін.) розглядають психологічну готовність у зв'язку з психологічними функціями, формування яких необхідне для досягнення високих результатів діяльності. Н. Левітов звертав увагу на залежність готовності як психічного стану, який може бути короткочасним і довготривалим, від індивідуальних особливостей людини, завдань, які вона розв'язує, а також умов іiі життєдіяльності [7].

У межах другого підходу, яскравим представником якого є грузинський психолог Д. Узнадзе, феномен готовності розглядається як психологічна настанова особистості, що $\epsilon$ основою формування готовності до діяльності та інших форм активності особистості. М. Клімова, дотримуючись поглядів О. Леонтьєва, вважає, що настанова не $\epsilon$ однотипним психічним явищем, а відрізняється походженням і видами [3]. На думку авторки, настанова породжується самою поведінкою, діяльністю і є важливою умовою для нових актів поведінки і діяльності особистості. Готовність не виникає поза межами настанов, якщо їх розуміти як налаштування суб'єкта на подальшу діяльність. Готовність передбачає не тільки різного роду настанови, але й усвідомлені завдання, моделі майбутньої поведінки, визначення оптимальних засобів діяльності, оцінку можливостей у співвідношенні 3 необхідністю досягнення конкретного результату. Вочевидь, стан настанови і готовності збігається лише в окремих випадках, загалом же готовність - більш складне структурне утворення.

Представники третього підходу (М. Дьяченко, Л. Кандибович, Л. Кобзар та ін.) уважають, що психологічна готовність до діяльності - це своєрідна форма відображення суб'єктом професійної діяльності, і поза відображенням готовність виникати не може. М. Дьяченко та Л. Кандибович розглядають готовність до діяльності у процесуальному та потенційному аспектах. У процесуальному аспекті готовність виявляється у здатності особистості до певних дій, наявності відповідних умінь і навичок, що передують досвіду. У потенційному аспекті на першому плані перебувають переважно мотиваційні (наявність бажання виконувати відповідну дію) й особистісні особливості (упевненість у собі, активність, уміння співпрацювати, вміння володіти педагогічною ситуацією, певний рівень емоційної саморегуляції) [7].

У наукових розвідках А. Линенко глибоко й різнобічно висвітлені особливості процесу формування готовності до педагогічної діяльності [5]. Дослідниця визначає такі компоненти готовності до педагогічної діяльності, як професійна самосвідомість, ставлення до діяльності, чи настанова (для ситуаційної готовності), мотиви, знання про предмет та способи діяльності, навички й уміння практичного втілення цих способів, а також професійно значущі якості особистості. У працях 3. Курлянд установлено зв'язок феномену професійно-педагогічної готовності з педагогічною усталеністю вчителя як синтезу властивостей і якостей його особистості, що надає змогу в межах здійснення своєї професійної діяльності упродовж тривалого часу виконувати іiі впевнено, самостійно, без емоційного напруження в різних, часто непередбачених умовах, 3 мінімальними помилками [6]. І. Богданова визначає готовність як цілісну інтегративну якість особистості, що характеризує ії емоційно-когнітивну та вибіркову прогнозуючу 
мобілізаційність у момент включення у діяльність певної спрямованості. Готовність, на iї думку, виникає внаслідок накопичення людиною досвіду, який грунтується на формуванні позитивного ставлення до діяльності, усвідомлення мотивів і потреб у ній, об’єктивізації предмета діяльності і способів взаємодії з ним. Тривала готовність (чи підготовленість) може бути сформована в результаті спеціально організованих впливів. Основними інваріантними та іманентними складниками готовності авторка визнає єдність особистісного та процесуального компонентів [1]. Т. Койчева підкреслює, що готовність до професійно-педагогічної діяльності грунтується на індивідуальних особливостях майбутнього вчителя як суб'єкта навчально-пізнавальної діяльності і $є$ вихідною характеристикою його особистісного становлення як педагогапрофесіонала [4]. Р. Гурін, досліджуючи особливості підготовки майбутнього вчителя гуманітарного профілю до застосування нових інформаційних технологій у навчальному процесі, окреслює готовність як інтегровану якість особистості майбутнього вчителя, що виявляється, по-перше, у підвищенні продуктивності мислення, розвитку пам'яті, навичок, розширенні і поглибленні знань за допомогою використання НIT та їх засобів; по-друге, у наданні можливості обирати способи дій, здійснювати самоконтроль за виконанням власних дій та прогнозувати шляхи підвищення продуктивності роботи у процесі інформатизації процесу навчання [2].

Зіставляючи погляди науковців-педагогів (І. Богданова, Р. Гурін, М. Клімова, 3. Курлянд, Т. Койчева, А. Линенко, Т. Подобєдова та ін.) на сутність понять «підготовка» і «Готовність», підготовку майбутніх учителів природничо-математичних дисциплін ми розглядаємо як процес, а готовність - як узагальнену характеристику якості результату процесу підготовки майбутнього вчителя до виконання професійних функцій.

Отже, готовність майбутнього вчителя природничо-математичних дисциплін до педагогічного проектування засобами інформаційних технологій ми розглядаємо як новоутворення у структурі особистості та іiі інтегративну характеристику, що має властивості динамічності, системності та багаторівневості і знаходить вияв у здатності педагога плідно використовувати інформаційні технології у проектуванні педагогічних процесів і систем та управлінні проектною діяльністю учнів.

Узагальнення результатів досліджень у галузі педагогічного проектування засобами нових інформаційних технологій (В. Алейников, В. Арнаутов, Р. Гурін, М. Жалдак, Т. Подобєдова та ін.) дозволило виокремити основні компоненти (мотиваційний; когнітивний; операційно-технологічний; особистісно-професійний) готовності вчителів природничо-математичних дисциплін до педагогічного проектування засобами інформаційних технологій, конкретизувати компоненти та елементи цієї готовності.

Так, мотиваиійний компонент (від лат. movere- приводити в дію, штовхати) визначається як усвідомлення майбутнім учителем мети i змісту педагогічного проектування, розуміння значення НІТ у професійно-педагогічній діяльності загалом і проектно-педагогічній діяльності зокрема, особистісне ставлення студента до науководослідної роботи в галузі педагогічного проектування. Показниками мотиваційного компонента визначено: інтерес до науково-дослідної роботи, наукового пошуку в галузі педагогічного проектування; самостійність у наукових пошуках; намагання активно оволодівати знаннями і вміннями в галузі педагогічного проектування; потреба в оволодінні новими інформаційними технологіями задля використання в педагогічному проектуванні; усвідомлення мети і змісту педагогічного проектування; бажання організовувати проектну діяльність учнів та керувати нею.

Когнітивний компонент (від лат. cognitio- знання, пізнання) у структурі готовності до проектної діяльності з використанням НІТ визначається як система знань і 
вмінь, якими повинен володіти сучасний учитель природничо-математичних дисциплін. Показниками когнітивного компоненту обрано рівні: спеціальних фахових знань; знань 3 дидактики та вміння використовувати їх у практиці викладання фахового предмета; знань методики викладання природничо-математичних дисциплін; знань нових інформаційних технологій та можливостей їх використання у процесі педагогічного проектування та управління проектною діяльністю учнів; психолого-педагогічних знань щодо мети, змісту, методів та засобів педагогічного проектування й управління проектною діяльністю учнів.

Операційно-технологічний компонент має відображати рівень володіння майбутніми вчителями засобами IT у процесі педагогічного проектування. Показниками цього компонента є: уміння використовувати IT для діагностики педагогічного процесу; уміння використовувати IT для прогнозування й організації педагогічного проектування; уміння використовувати IT для організації й оцінювання результатів проектної діяльності учнів під час вивчення природничо-математичних дисциплін.

Особистісно-професійний компонент схарактеризовано такими показниками, як: уміння об'єктивно оцінювати педагогічну ситуацію та використовувати оптимальні методи іiі розв'язання; уміння забезпечувати позитивну мотивацію та сприятливий психологічний мікроклімат взаємодії в системах «учитель - учень», «учень - учень» під час індивідуальної та колективної проектної діяльності; організувати співробітництво «у проектній команді»; наявність у педагога таких рис, як активність, толерантність, потреба у співробітництві; креативність; уміння об'єктивно оцінювати результати педагогічного проектування засобами IT та коригувати їх.

Узагальнюючи викладене, зазначимо, що під готовністю майбутніх учителів природничо-математичних дисциплін до педагогічного проектування з використанням нових інформаційних технологій ми розуміємо інтегративне особистісне утворення, яке виявляється на суб'єктивному рівні як складна система, котра синтезує в собі мотиваційний, когнітивний, операційно-технологічний та особистісно-професійний компоненти, складниками яких $є$ знання сутності педагогічного проектування і нових інформаційних технологій та вміння використовувати їх в організації і самооцінці власної проектно-педагогічної діяльності й управлінні проектною діяльністю учнів.

Перспективи подальших розвідок ми вбачаємо в розгляді чинників й умов, які впливають на розвиток готовності майбутнього вчителя природничо-математичних дисциплін до педагогічного проектування засобами інформаційних технологій під час навчання у вищих педагогічних закладах.

\section{Література}

1. Богданова I. М. Прикладна педагогіка: дидактичні можливості інформаційномодульної технології : [методичні рекомендації] / Інна Михайлівна Богданова. - Одеса : Південноукраїнський державний педагогічний університет імені К. Д. Ушинського, 2001. - 79 с. 2. Гурін Р. С. Підготовка майбутнього вчителя гуманітарного профілю до застосування нових інформаційних технологій у навчальному процесі загальноосвітньої школи : дис. ... канд. пед. наук: 13.00.04 / Гурін Руслан Сергійович. - Одеса, 2004. 222 с. 3. Климова М. В. Сущность понятия «готовность будущего учителя к использованию экспертных систем в профессиональной деятельности» // Материалы Х Всероссийской научн.-практ. конф. [«Методология и методика формирования научных понятий у учащихся школ и студентов вузов»] / М. В. Климова. - Челябинск : Изд-во ЧГПУ, 2004. - Ч. І. - С. 223-226. 4. Койчева Т. І. Підготовка майбутніх учителів гуманітарних спеціальностей як тьюторів для системи дистанційної освіти : дис. ... канд. пед. наук : 13.00.04/ Койчева Тетяна Іванівна. - Одеса, 2004. - 304 с. 5. Линенко А. Ф. Готовність майбутніх учителів до педагогічної діяльності / 
А. Ф. Линенко // Педагогіка і психологія. - 1995. - № 1. - С. 125-132. 6. Педагогіка вищої школи : [навч. посібник] / [3. Н. Курлянд, Р. І. Хмелюк, А. В. Семенова та ін.] ; за ред. 3. Н. Курлянд. - [3-є вид., перероб. і доп.]. - К. : Знання, 2007. - 495 с. 7. Перець О. Б. Підготовка майбутніх учителів природничо-математичних дисциплін до педагогічного проектування засобами інформаційних технологій: дис. ... канд. пед. наук: 13.00.04 / Перець Ольга Борисівна. - Одеса, 2010. - 300 с.

УДК 37: 33 -057: 159.923: $811 \ll 71 »$

Олена Семеног, Андрій Семеног

\section{СУЧАСНИЙ ЕКОНОМІСТ ЯК ПРОФЕСІЙНА МОВНА ОСОБИСТІСТЬ: УСПІХИ І ПРОБЛЕМИ СТАНОВЛЕННЯ В УМОВАХ ВИЩОЇ ЕКОНОМІЧНОЇ ШКОЛИ}

Семеног О. М., Семеног А. Ю. Сучасний економіст як професійна мовна особистість: успіхи і проблеми становлення в умовах вищої економічної школи.

У статті розглядаються окремі аспекти вияву мовної, термінологічної, комунікативно-прагматичної, текстової, дискурсивної компетенцій мовної особистості фахівця економічної сфери. Окреслюється вплив особистісних рис економіста як наставника на формування мовної особистості студента - майбутнього економіста.

Ключові слова: економіст, професійний економічний текст, мовна особистість, мовна, термінологічна, комунікативно-прагматична, текстова, дискурсивна компетенції.

Семеног Е. Н., Семеног А. Ю. Современный экономист как профессиональная языковая личность: успехи и проблемы становления в условиях высшей экономической школы.

Статья посвящена рассмотрению отдельных аспектов проявления языковой, терминологической, коммуникативно-прагматической, текстовой, дискурсивной компетенций языковой личности специалиста экономической сферы. Охарактеризовано влияние личности экономиста как наставника на формирование языковой личности студента - будущего экономиста.

Ключевые слова: экономист, профессиональный экономический текст, языковая личность, языковая, терминологическая, коммуникативно-прагматическая, текстовая, дискурсивная компетенции.

Semenog O. N., Semenog A. Y. Modern economist as a professional linguistic personality: success and challenges of formation in Higher Economics School.

The report is devoted to the certain aspects of language, terminology, communicative, textual, discursive competence of the person skilled in economic sphere. The presentation describes the influence of the individual of economist on the formation of the linguistic identity of the student - the future economist.

Key words: economist, professional linguistic text, linguistic personality, the language, terminology, communicative, textual, discursive competence.

Вимоги роботодавців зактуалізовують такі професійно важливі якості економістів, як творчий та аналітичний стиль мислення, емоційна стабільність і самовладання, здатність генерувати нове розв' язання нестандартних виробничих ситуацій і практичних задач, усвідомлення культурних зразків професії. Визначальними в досягненні фахового успіху є вміння аргументовано будувати усне і писемне професійно-ділове спілкування, інтерпретувати готовий і створювати власний професійний економічний текст, a їх 